\title{
The Effects of $\mathrm{CO}_{2}$ Injection and Barrel Temperatures on the Physiochemical and Antioxidant Properties of Extruded Cereals
}

\author{
Thazin Thin ${ }^{1}$, Lin Myat ${ }^{2}$, and Gi-Hyung Ryu ${ }^{1}$ \\ ${ }^{1}$ Department of Food Science and Technology, Kongju National University, Chungnam 32588, Korea \\ ${ }^{2}$ Department of Plant Pathology, Yezin Agricultural University, Pyinmana, Myanmar
}

\begin{abstract}
The effects of $\mathrm{CO}_{2}$ injection and barrel temperatures on the physiochemical and antioxidant properties of extruded cereals (sorghum, barley, oats, and millet) were studied. Extrusion was carried out using a twin-screw extruder at different barrel temperatures $\left(80,110\right.$, and $\left.140^{\circ} \mathrm{C}\right), \mathrm{CO}_{2}$ injection $(0$ and $500 \mathrm{~mL} / \mathrm{min})$, screw speed of $200 \mathrm{rpm}$, and moisture content of $25 \%$. Extrusion significantly increased the total flavonoid content (TFC) of extruded oats, and $\beta$-glucan and protein digestibility (PD) of extruded barley and oats. In contrast, there were significant reductions in 1,1-diphenyl-2-picrylhydrazyl (DPPH) radical scavenging activity, PD of extruded sorghum and millet, as well as resistant starch (RS) of extruded sorghum and barley, and total phenolic content (TPC) of all extrudates, except extruded millet. At a barrel temperature of $140^{\circ} \mathrm{C}$, TPC in extruded barley was significantly increased, and there was also an increase in DPPH and PD in extruded millet with or without $\mathrm{CO}_{2}$ injection. In contrast, at a barrel temperature of $140^{\circ} \mathrm{C}$, the TPC of extruded sorghum decreased, TFC of extruded oats decreased, and at a barrel temperature of $110^{\circ} \mathrm{C}$, PD of extruded sorghum without $\mathrm{CO}_{2}$ decreased. Some physical properties [expansion ratio (ER), specific length, piece density, color, and water absorption index] of the extrudates were significantly affected by the increase in barrel temperature. The $\mathrm{CO}_{2}$ injection significantly affected some physical properties (ER, specific length, piece density, water solubility index, and water absorption index), TPC, DPPH, $\beta$-glucan, and PD. In conclusion, extruded barley and millet had higher potential for making value added cereal-based foods than the other cereals.
\end{abstract}

Keywords: cereals, physiochemical properties, antioxidant properties, extrusion, $\mathrm{CO}_{2}$ injection

\section{INTRODUCTION}

Cereal grains are generally used as the major raw materials for extruded snack foods due to their good expansion characteristics and high starch content. Sorghum and millet are important cereals in many parts of Africa, Asia, and the semi-arid tropics worldwide. Sorghum is widely used for animal feed and human food, and its bioactive components might increase its use in foods (1). In recent years, millets have received attention, mainly because of their high fiber content, which can be provided in convenient forms to consumers (2). Barley is also a widely consumed cereal among the ancient cereal crops. Almost $80 \sim 90 \%$ of barley production is for animal feed and malt, but now barley is gaining renewed interest as an ingredient for production of functional foods due to their concentration of bioactive compounds such as $\beta$-glucans and tocols $(3,4)$. Oats are one of the most valuable cereal grains since they contain a variety of natural health-pro- moting components such as $\beta$-glucans.

Extrusion is one of the most important food processing techniques widely used for production of various types of food products such as cereal-based snack foods and ready-to-eat breakfast cereals (5). During extrusion, biopolymers formed by gelatinization of starch and denaturation of proteins, have several effects on the physicochemical properties of the extrudates (6). During extrusion, the $\mathrm{CO}_{2}$ injection enables the formation of an expanded structure, where the $\mathrm{CO}_{2}$ functions as a blowing agent instead of steam in traditional extrusion. During the $\mathrm{CO}_{2}$ injection process, nucleated bubbles are expanded by hydrodynamic effects, and $\mathrm{CO}_{2}$ diffuses into the growing bubbles from the surrounding melt (7). The diffusion driven by concentration difference provides more controlled expansion than puffing by water flash-off.

In terms of the physical properties, the extent of expansion of the extrudate is important as it influences the porous structure (8). Besides, changes in hydration prop-

Received 31 March 2016; Accepted 5 June 2016; Published online 30 September 2016

Correspondence to Gi-Hyung Ryu, Tel: +82-41-330-1484, E-mail: ghryu@kongju.ac.kr

Copyright (C) 2016 by The Korean Society of Food Science and Nutrition. All rights Reserved.

(c) This is an Open Access article distributed under the terms of the Creative Commons Attribution Non-Commercial License (http://creativecommons.org/licenses/by-nc/4.0) which permits unrestricted non-commercial use, distribution, and reproduction in any medium, provided the original work is properly cited. 
erties such as water absorption index (WAI) and water solubility index (WSI) have been reported to affect both the ability of feed to mix with digestive enzymes and the general behavior of feed in the digestive tract of monogastric animals (9), and to affect extrudate stability in water which is an important property in fish and aquaculture feeds.

Starch is an important component in cereals. Extrusion cooking is known to influence the yield of resistant starch (RS) in foods (10). The RS content of native flours of hull-less barley (waxy and regular), in general, decreased by extrusion cooking, but not significantly (11). The retention of cereal protein quality and quantity during processing is important for dietary reasons. Fapojuwo et al. (12) observed that extrusion temperature improved in vitro protein digestibility of 2 low tannin sorghum varieties. Ejeta et al. (13) reported that the digestibility values for the cooked pearl millet varieties were higher than that of sorghum and was comparable to that of maize. Die temperature had a significant effect on $\beta$-glucan from barley flour and barley-grape pomace extrudates (14). On the other hand, Yao et al. (15) reported that changing the extrusion temperature or moisture content did not affect $\beta$-glucan from oat. The barrel temperature and $\mathrm{CO}_{2}$ injection significantly affected the physical properties of extruded germinated wheat and barley and increased $\beta$-glucan in extruded germinated wheat (16). In view of the antioxidant properties, extrusion cooking decreased the antioxidant activity and total phenolics of barley, barley-tomato pomace, and barley-grape pomace extrudates (14). Researchers reported the reduction of total phenolic content by extrusion in oat cereals and oat extrudates $(17,18)$. While cereal extrusion of wheat and maize has been studied extensively (19), the cereals investigated in this research have been studied by some researchers.

According to the observations mentioned above, it was of interest to study the selected 4 cereals extruded at different conditions. Therefore, this research was carried out to determine the effects of $\mathrm{CO}_{2}$ injection and barrel temperatures on the physiochemical and antioxidant properties of extruded cereals.

\section{MATERIALS AND METHODS}

\section{Materials}

Sorghum, barley, oats, and millet grains were purchased at a local market in Korea and ground to flour for use in this experiment. The moisture content was calculated using the Association of the Official Analytical Chemists (20) drying method in which the sample ( $3 \mathrm{~g})$ was dried in an oven at $135^{\circ} \mathrm{C}$ for $1 \mathrm{~h}$ and cooled for $30 \mathrm{~min}$. The moisture contents of sorghum, barley, oats, and millet were $7.73,8.46,6.81$, and $9.19 \%$, respectively.

\section{Extrusion process}

Extrusion was performed in a twin-screw extruder (Incheon Machinery Co., Incheon, Korea) equipped with a 32-mm diameter at a length to diameter ratio of 23:1. The extrusion conditions were $\mathrm{CO}_{2}$ injection of $500 \mathrm{~mL} /$ min, different barrel temperatures $\left(80,110\right.$, and $\left.140^{\circ} \mathrm{C}\right)$, and die diameter of $3 \mathrm{~mm}$. The screw configuration is shown in Fig. 1. The moisture content $(25 \%)$ and screw speed $(200 \mathrm{rpm})$ were fixed. After extrusion, the samples were dried in an oven at $55^{\circ} \mathrm{C}$ for $8 \mathrm{~h}$ and then ground to powder using a stainless blender. The grounded samples were passed through a $600 \mu \mathrm{m}$ sieve and stored in plastic bags at room temperature for analysis.

\section{Physical properties}

Expansion ratio (ER) and specific length: The ER was determined as the diameter of extrudates divided by the diameter of the dye $(3 \mathrm{~mm})$. The specific length was evaluated as the length of extrudates divided by the weight of extrudates (21). Ten measurements were taken for each sample.

Piece density: The piece density of the extrudates was determined by the millet seed displacement method. The extrudates $(2 \sim 5 \mathrm{~g})$ were placed in the $125 \mathrm{~mL}$ cup and then filled with millet seeds. The cup with extrudates and millet seeds were weighed. The piece density was obtained by using the following equation. Triplicates were taken for each sample.

$$
\mathrm{Pe}=\frac{\mathrm{M} \times \mathrm{Pm}}{\mathrm{M}+\mathrm{M}_{0}-\mathrm{M}_{1}}
$$

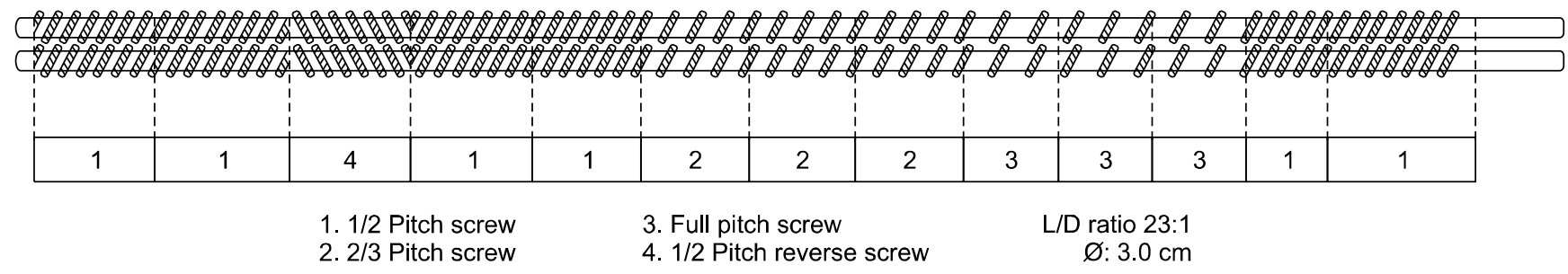

Fig. 1. Screw configuration of the twin-screw extruder. 
where Pe is piece density of extrudate $\left(\mathrm{g} / \mathrm{cm}^{3}\right), \mathrm{Pm}$ is piece density of millet $\left(\mathrm{g} / \mathrm{cm}^{3}\right), M$ is mass of extrudate (g), $M_{0}$ is mass of millet in tube $(\mathrm{g})$, and $\mathrm{M}_{1}$ is mass of extrudate and millet in tube (g).

Color: A colorimeter (Minolta JP/CR-300, Konica Minolta, Tokyo, Japan) was used to determine the color of ground extruded samples as lightness $\left(L^{*}\right)$, redness $\left(a^{*}\right)$, and yellowness $\left(b^{*}\right)$. In the colorimeter, the color was calibrated against the standard white $\left(L^{*}=97.42, a^{*}=-0.19\right.$, and $\left.b^{*}=-1.71\right)$. The lightness was denoted by the $L^{*}$ value (from white 100 to black 0 ). The redness and yellowness was denoted by $a^{*}$ values (from green to red) and the $b^{*}$ values (from blue to yellow), respectively. Each sample was measured in triplicates.

WAI and WSI: WAI and WSI were determined by the method of Anderson et al. (22). The sample (3 g) was mixed with $25 \mathrm{~mL}$ of distilled water in a centrifuge tube, which was vigorously agitated in a laboratory shaker until complete dispersion and then placed in a shaker (110 rpm) for $30 \mathrm{~min}$ at $30^{\circ} \mathrm{C}$. The suspension was centrifuged at $3,000 \mathrm{~g}$ for $20 \mathrm{~min}$. WAI was expressed as the weight precipitated per gram of sample. The supernatant was evaporated in an oven at $105^{\circ} \mathrm{C}$ until dry, and the WSI was the weight of dry solids in the supernatant represented as a percentage of the sample's original weight.

\section{Chemical properties}

Protein digestibility (PD): The PD was determined by a modified method from Mertz et al. (23). The sample (200 $\mathrm{mg}$ ) was suspended with $35 \mathrm{~mL}$ of pepsin solution (1.5 $\mathrm{g}$ of enzyme/1,000 $\mathrm{mL}$ of $0.084 \mathrm{~N} \mathrm{HCL})$. These samples were digested at $37^{\circ} \mathrm{C}$ for $2 \mathrm{~h}$ in a shaker at $150 \mathrm{rpm}$. After digestion, $2 \mathrm{~mL}$ of $2 \mathrm{M} \mathrm{NaOH}$ was added to stop enzyme activity. These solutions were centrifuged at 3,000 $g$ for $15 \mathrm{~min}$. After centrifugation, the supernatant was decanted, and the residue was washed with $10 \mathrm{~mL}$ of 0.1 $\mathrm{M}$ phosphate buffer. As described above, the residue was washed 2 times. The undigested residues were dried at $30^{\circ} \mathrm{C}$ in an oven until dried. These samples were used to analyze the total protein content using the ninhydrin based method (24). The percentage of PD was calculated by subtracting the undigested protein from the total protein, divided by the total protein, and multiplied by 100 (25).

$\beta$-Glucan: The $\beta$-glucan content was determined according to the procedure of the mixed-linkage beta-glucan assay kit (Megazyme International Ireland, Bray, Wicklow, Ireland). One milliliter of aqueous ethanol $(50 \% \mathrm{v} / \mathrm{v})$ was added to each sample $(0.5 \mathrm{~g})$. Then, 5.0 $\mathrm{mL}$ of sodium phosphate buffer $(20 \mathrm{mM}, \mathrm{pH} 6.5)$ was added to the solution tubes and then vortexed. The tubes were incubated in a boiling water bath for $2 \mathrm{~min}$ and then vortexed to prevent the formation of a lump of gel material. The tubes were heated again for $3 \mathrm{~min}$ in the boiling water bath and cooled to $40^{\circ} \mathrm{C}$. Lichenase $(0.2 \mathrm{~mL})$ was added to each tube and incubated at $40^{\circ} \mathrm{C}$ for $1 \mathrm{~h}$. The volume was adjusted to $30 \mathrm{~mL}$ with distilled water and then thoroughly mixed the contents of the tubes. These tubes were centrifuged at $1,000 \mathrm{~g}$ for 10 min. Aliquots $(0.1 \mathrm{~mL})$ were taken from each tube and transferred to blank reaction tubes with $0.1 \mathrm{~mL}$ of sodium acetate buffer $(50 \mathrm{mM}, \mathrm{pH} 4.0)$ and the reaction tubes with $0.1 \mathrm{~mL}$ of $\beta$-glucosidase $(0.2 \mathrm{U})$ in $50 \mathrm{mM}$ acetate buffer ( $\mathrm{pH} 4.0)$. These tubes were incubated at $40^{\circ} \mathrm{C}$ for $15 \mathrm{~min}$. After that, $3.0 \mathrm{~mL}$ of glucose oxidase/peroxidase (GOPOD) reagent (glucose determination reagent) was added to each tube and incubated at $40^{\circ} \mathrm{C}$ for $20 \mathrm{~min}$. The absorbance was measured at 510 $\mathrm{nm}$ using a spectrophotometer. D-glucose was used as the standard for determination of $\beta$-glucan. The content of $\beta$-glucan was calculated by the following equation:

$$
\beta \text {-Glucan }(\% \mathrm{w} / \mathrm{w})=\triangle \mathrm{A} \times \frac{\mathrm{F}}{\mathrm{W}} \times 27
$$

where $\triangle \mathrm{A}$ is absorbance after $\beta$-glucosidase treatment (reaction) minus reaction blank absorbance, $\mathrm{F}$ is a factor for the conversion of absorbance values to $\mu$ g of glucose, and $\mathrm{W}$ is the calculated dry weight of the sample (mg).

$R S$ : The RS contents were measured according to the procedure of the RS assay kit (Megazyme International Ireland). The sample $(100 \mathrm{mg})$ was treated with $4 \mathrm{~mL}$ of pancreatic $\alpha$-amylase solution made by the mixture of pancreatic $\alpha$ amylase and amyloglucosidase, $300 \mathrm{U} / \mathrm{mL}$ ) and incubated in a shaking water bath at a rate of 200 strokes $/ \mathrm{min}$ at $37^{\circ} \mathrm{C}$ for $16 \mathrm{~h}$. After incubation, $4 \mathrm{~mL}$ of ethanol $(99 \% \mathrm{v} / \mathrm{v})$ was added to stop the reaction and centrifuged at 3,000 $\mathrm{g}$ for $10 \mathrm{~min}$. The supernatant was carefully decanted, and the residue was mixed with $8 \mathrm{~mL}$ of $50 \%$ ethanol followed by centrifugation at $3,000 \mathrm{~g}$ for $10 \mathrm{~min}$. The $50 \%$ ethanol-washing step was repeated once more. Two milliliters of $\mathrm{KOH}$ was added to the pellets, followed by stirring in an iced water bath for 20 min. At that point, $8 \mathrm{~mL}$ of $1.2 \mathrm{M}$ sodium acetate buffer $(\mathrm{pH}$ 3.8) was added and stirred on a magnetic stirrer. Then, $0.1 \mathrm{~mL}$ of amyloglucosidase $(3,300 \mathrm{U} / \mathrm{mL})$ was immediately added and mixed well. The incubation process was done in a water bath at $50^{\circ} \mathrm{C}$ for $30 \mathrm{~min}$ followed by centrifugation at $3,000 \mathrm{~g}$ for $10 \mathrm{~min}$. After centrifugation, $0.1 \mathrm{~mL}$ of aliquots (in duplicate) were taken from the supernatant and treated with $3 \mathrm{~mL}$ of GOPOD reagent. Samples were incubated at $50^{\circ} \mathrm{C}$ for $20 \mathrm{~min}$. Absorbance was measured at $510 \mathrm{~nm}$ against the reagent blank using a spectrophotometer. D-glucose standard was used in this determination. The content of RS was calculated by the following equation: 


$$
\mathrm{RS}(\%)=\Delta \mathrm{E} \times \frac{\mathrm{F}}{\mathrm{W}} \times 9.27
$$

where $\triangle \mathrm{E}$ is absorbance (reaction) read against the reagent blank, $\mathrm{F}$ is a factor for the conversion of absorbance values to $\mu \mathrm{g}$ of glucose, and $\mathrm{W}$ is dry weight of sample.

\section{Antioxidant properties \\ Total phenolic content (TPC): The TPC was determined ac- cording to the method of Slinkard and Singleton (26). The sample (1 g) was extracted with $10 \mathrm{~mL}$ of $80 \%$ meth- anol. The centrifugation was done at 3,000 $\mathrm{g}$ for $30 \mathrm{~min}$ after incubation at room temperature for $2 \mathrm{~h}$. The super- natant $(300 \mu \mathrm{L})$, taken from extraction, was mixed with $1.5 \mathrm{~mL}$ of $10 \%$ (v/v) Folin-Ciocalteu reagent. This sol- ution was vortexed and allowed to react for $5 \mathrm{~min}$. After the reaction, $1.5 \mathrm{~mL}$ of $\mathrm{Na}_{2} \mathrm{CO}_{3}$ solution $(60 \mathrm{~g} / \mathrm{L})$ was added to this solution and then was incubated again at room temperature for $2 \mathrm{~h}$. The absorbance of the sample solution was measured at $765 \mathrm{~nm}$ using a spectrophoto- meter. The concentration of TPC was determined as mil- ligrams of gallic acid equivalent (GAE) per gram of dry sample using an equation obtained from the gallic acid standard curve.}

Total flavonoid content (TFC): The TFC was measured according to the method of Ebrahimzadeh et al. (27). The sample ( $1 \mathrm{~g}$ ) mixed with $10 \mathrm{~mL}$ of $80 \%$ methanol was extracted at room temperature for $2 \mathrm{~h}$ and then centrifuged at 3,000 $\mathrm{g}$ for $30 \mathrm{~min}$. The supernatant $(0.5 \mathrm{~mL})$ was taken from the extracted sample each, and then mixed with $1.5 \mathrm{~mL}$ of methanol and $0.1 \mathrm{~mL}$ of $10 \%$ aluminum chloride. Then, $0.1 \mathrm{~mL}$ of $1 \mathrm{M}$ potassium acetate and $2.8 \mathrm{~mL}$ of distilled water were added to this sample. The sample was incubated at room temperature for 30 min. The absorbance was measured at $415 \mathrm{~nm}$ using a spectrophotometer. Milligrams of quercetin per gram of dry sample, using an equation obtained from the quercetin standard curve, were used as the concentration for determination of TFC.

1,1-Diphenyl-2-picrylhydrazyl (DPPH) radical scavenging activity: The DPPH radical scavenging activity was determined according to the method of Brand-Williams et al. (28). The extraction of the sample ( $1 \mathrm{~g}$ ) was done with $80 \%$ methanol at room temperature for $2 \mathrm{~h}$ and centrifuged at 3,000 $\mathrm{g}$ for $30 \mathrm{~min}$. The DPPH solution was made at a rate of $0.0024 \mathrm{~g}$ of DPPH in $100 \mathrm{~mL}$ of methanol. Then, $3.9 \mathrm{~mL}$ of DPPH solution was added to 0.1 $\mathrm{mL}$ of the supernatant. After incubation at room temperature for $30 \mathrm{~min}$ in the dark, the absorbance was read at $515 \mathrm{~nm}$. The DPPH radical scavenging percentage was determined with the following equation:
Radical scavenging activity $(\%)=\frac{A_{o}-A_{i}}{A_{o}} \times 100$

where $A_{o}$ is absorbance of control and $A_{i}$ is absorbance of sample.

\section{Statistical analysis}

Data were analyzed using the SPSS program (Version 12.0.1, SPSS Inc., Chicago, IL, USA). Duncan's least significant difference (LSD) tests were used to analyze the differences between mean values of the treatments. Significant differences were determined at $P<0.05$.

\section{RESULTS AND DISCUSSION}

\section{Physical properties}

ER and specific length: As shown in Table 1, the ER values of extrudates ranged from 1.23 to 2.70. Depending on the sample and the injection of $\mathrm{CO}_{2}$, various trends were observed between the barrel temperature and ER. Extruded millet without $\mathrm{CO}_{2}$ injection and extruded oats with $\mathrm{CO}_{2}$ injection showed significant increases in ER with increasing barrel temperature. Extruded oats without $\mathrm{CO}_{2}$ injection at $140^{\circ} \mathrm{C}$ also showed a significant increase in ER as the barrel temperature increased. Huth et al. (29) reported similar results that increased barrel temperature leads to a significant increase in ER of extruded barley. When the barrel temperature increased from 80 to 110 ${ }^{\circ} \mathrm{C}$, ER of extruded sorghum and extruded barley significantly increased and then significantly decreased when extruded at $140^{\circ} \mathrm{C}$. In extruded millet with $\mathrm{CO}_{2}$ injection, there was a significant decrease from 1.51 to 1.23 as the temperature increased from 80 to $140^{\circ} \mathrm{C}(P<0.05)$. It was found that if the temperature is higher than the critical temperature, expansion decreases due to excessive softening and potential structural degradation of the starch melt, which becomes unable to withstand the high vapor pressure (30). The $\mathrm{CO}_{2}$ injection significantly increases ER of extruded sorghum, extruded barley, and extruded millet at $80^{\circ} \mathrm{C}$. On the other hand, $\mathrm{CO}_{2}$ injection decreased ER of extruded sorghum and extruded barley at $140^{\circ} \mathrm{C}$, and extruded millet $\left(110^{\circ} \mathrm{C}\right.$ and $\left.140^{\circ} \mathrm{C}\right)$.

In this study, when the barrel temperature increased, the specific length significantly increased in all extrudates without $\mathrm{CO}_{2}$ injection at $140^{\circ} \mathrm{C}(P<0.05)$. There was a significant increase in specific length of all extrudates with $\mathrm{CO}_{2}$ injection except for the extruded sorghum with $\mathrm{CO}_{2}$ injection as the barrel temperature increased. The decrease in expansion and the increase in specific length have been attributed to increased dextrinization and weakening of the structure (31).

Piece density: The result of piece density in this study is shown in Table 1. Piece density has been linked to the 
Table 1. Effects of $\mathrm{CO}_{2}$ injection and barrel temperatures on the physical properties of extruded cereals

\begin{tabular}{|c|c|c|c|c|c|c|c|c|c|c|}
\hline \multirow{2}{*}{ Sample } & \multirow{2}{*}{$\begin{array}{c}\mathrm{CO}_{2} \\
\text { injection }\end{array}$} & \multirow{2}{*}{$\begin{array}{c}\text { Temperature } \\
\left({ }^{\circ} \mathrm{C}\right)\end{array}$} & \multirow{2}{*}{ ER } & \multirow{2}{*}{$\begin{array}{c}\text { Specific } \\
\text { length }(\mathrm{m} / \mathrm{kg})\end{array}$} & \multirow{2}{*}{$\begin{array}{l}\text { Piece density } \\
\left(\mathrm{g} / \mathrm{cm}^{3}\right)\end{array}$} & \multicolumn{3}{|c|}{ Color $^{1)}$} & \multirow{2}{*}{ WSI (\%) } & \multirow{2}{*}{ WAI $(\mathrm{g} / \mathrm{g}$} \\
\hline & & & & & & $L^{*}$ & $a^{*}$ & $b^{*}$ & & \\
\hline \multirow[t]{7}{*}{ Sorghum } & Raw & - & - & - & - & $81.38^{d}$ & $2.27^{f}$ & $10.21^{i}$ & $3.45^{h}$ & $1.12^{\mathrm{m}}$ \\
\hline & Non- $\mathrm{CO}_{2}$ & 80 & $1.27^{\mathrm{ij}}$ & $69.15^{\mathrm{ghi}}$ & $0.57^{\mathrm{ab}}$ & $62.73^{\mathrm{m}}$ & $7.69^{d}$ & $16.18^{\text {cdef }}$ & $9.08^{\mathrm{abc}}$ & $1.98^{\mathrm{kl}}$ \\
\hline & & 110 & $2.41^{b}$ & $77.89^{\mathrm{fg}}$ & $0.22^{\mathrm{ij}}$ & $63.38^{\mathrm{m}}$ & $7.94^{c}$ & $16.14^{\text {cdef }}$ & $9.14^{\mathrm{abc}}$ & $1.71^{\prime}$ \\
\hline & & 140 & $2.15^{d}$ & $93.99^{d}$ & $0.20^{\mathrm{ij}}$ & $58.67^{n}$ & $9.27^{a}$ & $15.92^{\mathrm{ef}}$ & $7.97^{\mathrm{bcd}}$ & $2.42^{\mathrm{hij}}$ \\
\hline & $\mathrm{CO}_{2}$ & 80 & $1.67^{f}$ & $69.13^{\mathrm{ghi}}$ & $0.40^{\text {def }}$ & $66.74^{\prime}$ & $7.29^{\mathrm{e}}$ & $16.61^{\text {cdef }}$ & $10.97^{\mathrm{a}}$ & $2.32^{\mathrm{ijk}}$ \\
\hline & & 110 & $2.28^{\mathrm{bcd}}$ & $73.32^{\text {fgh }}$ & $0.24^{\mathrm{hij}}$ & $65.78^{\prime}$ & $7.53^{d}$ & $16.05^{\text {def }}$ & $9.69^{\mathrm{ab}}$ & $2.06^{\mathrm{jkl}}$ \\
\hline & & 140 & $1.58^{\mathrm{fg}}$ & $69.13^{\mathrm{ghi}}$ & $0.38^{\text {def }}$ & $63.24^{\mathrm{m}}$ & $8.19^{b}$ & $15.63^{f}$ & $5.82^{\mathrm{efg}}$ & $2.30^{\mathrm{ijk}}$ \\
\hline \multirow[t]{7}{*}{ Barley } & Raw & - & - & - & - & $91.25^{a}$ & $0.74^{n}$ & $5.28^{j}$ & $5.63^{\mathrm{fg}}$ & $0.95^{\mathrm{m}}$ \\
\hline & $\mathrm{Non}-\mathrm{CO}_{2}$ & 80 & $1.85^{\mathrm{e}}$ & $34.63^{\mathrm{Im}}$ & $0.57^{\mathrm{ab}}$ & $74.87^{\text {gh }}$ & $1.43^{\mathrm{ijk}}$ & $13.36^{\mathrm{g}}$ & $6.89^{\mathrm{efg}}$ & $4.74^{\mathrm{bc}}$ \\
\hline & & 110 & $2.70^{a}$ & $42.93^{\mathrm{kl}}$ & $0.27^{\text {ghi }}$ & $74.91^{\text {gh }}$ & $1.66^{\mathrm{gh}}$ & $13.93^{9}$ & $5.51^{\mathrm{fg}}$ & $2.71^{\mathrm{hi}}$ \\
\hline & & 140 & $2.39^{b c}$ & $66.10^{\mathrm{hij}}$ & $0.21^{\mathrm{ij}}$ & $74.35^{\mathrm{h}}$ & $1.70^{\mathrm{gh}}$ & $14.34^{g}$ & $5.77^{\mathrm{efg}}$ & $3.38^{\mathrm{ef}}$ \\
\hline & $\mathrm{CO}_{2}$ & 80 & $2.40^{\mathrm{bc}}$ & $31.30^{1 \mathrm{~m}}$ & $0.45^{c d}$ & $74.07^{\mathrm{hi}}$ & $1.73^{\mathrm{g}}$ & $14.19^{g}$ & $7.50^{\text {cdef }}$ & $4.54^{c}$ \\
\hline & & 110 & $2.66^{\mathrm{a}}$ & $46.10^{k}$ & $0.25^{\mathrm{hij}}$ & $75.35^{\text {gh }}$ & $1.68^{\mathrm{gh}}$ & $13.82^{g}$ & $6.47^{\text {defg }}$ & $2.79^{g h}$ \\
\hline & & 140 & $1.87^{\mathrm{e}}$ & $108.24^{c}$ & $0.25^{\mathrm{hij}}$ & $79.50^{\mathrm{e}}$ & $0.81^{\mathrm{n}}$ & $11.41^{\mathrm{h}}$ & $7.70^{\text {cde }}$ & $3.14^{\mathrm{fg}}$ \\
\hline \multirow[t]{7}{*}{ Oats } & Raw & - & - & - & - & $87.89^{b}$ & $0.33^{\circ}$ & $9.62^{j}$ & $5.41^{g}$ & $0.96^{\mathrm{m}}$ \\
\hline & Non- $\mathrm{CO}_{2}$ & 80 & $1.23^{j}$ & $75.10^{\mathrm{fgh}}$ & $0.47^{c d}$ & $73.88^{\text {hij }}$ & $1.56^{\mathrm{ghi}}$ & $16.95^{\text {cde }}$ & $2.95^{\mathrm{hij}}$ & $3.31^{\text {ef }}$ \\
\hline & & 110 & $1.27^{\mathrm{ij}}$ & $83.35^{\mathrm{ef}}$ & $0.44^{\mathrm{cdf}}$ & $75.30^{\text {gh }}$ & $1.30^{\mathrm{kl}}$ & $16.86^{\text {cde }}$ & $2.72^{\mathrm{hij}}$ & $3.47^{\text {ef }}$ \\
\hline & & 140 & $1.66^{f}$ & $107.35^{c}$ & $0.35^{\mathrm{efg}}$ & $75.35^{g h}$ & $1.05^{\mathrm{m}}$ & $16.52^{\text {cdef }}$ & $3.13^{\mathrm{hij}}$ & $3.37^{\text {ef }}$ \\
\hline & $\mathrm{CO}_{2}$ & 80 & $1.25^{\mathrm{j}}$ & $78.31^{\mathrm{fg}}$ & $0.51^{b c}$ & $73.97^{\text {hij }}$ & $1.52^{\mathrm{hij}}$ & $17.25^{c}$ & $2.63^{\text {hij }}$ & $3.52^{\mathrm{ef}}$ \\
\hline & & 110 & $1.41^{\mathrm{hi}}$ & $91.25^{\mathrm{de}}$ & $0.38^{\text {def }}$ & $76.13^{g}$ & $1.14^{\mathrm{Im}}$ & $16.11^{\text {cdef }}$ & $2.57^{\mathrm{hij}}$ & $3.65^{\mathrm{e}}$ \\
\hline & & 140 & $1.57^{\mathrm{fg}}$ & $115.16^{\mathrm{bc}}$ & $0.25^{\mathrm{hij}}$ & $74.70^{g h}$ & $1.00^{m}$ & $16.68^{\text {cdef }}$ & $2.82^{\text {hij }}$ & $3.40^{\text {ef }}$ \\
\hline \multirow[t]{7}{*}{ Millet } & Raw & - & - & - & - & $83.80^{c}$ & $0.78^{n}$ & $17.19^{c d}$ & $3.31^{\mathrm{hi}}$ & $0.95^{\mathrm{m}}$ \\
\hline & Non- $\mathrm{CO}_{2}$ & 80 & $1.33^{\mathrm{ij}}$ & $62.11^{\mathrm{ij}}$ & $0.60^{a}$ & $73.89^{\text {hij }}$ & $1.36^{\mathrm{jk}}$ & $21.79^{a}$ & $1.19^{k}$ & $2.71^{\mathrm{hi}}$ \\
\hline & & 110 & $1.67^{f}$ & $58.07^{j}$ & $0.35^{\text {efg }}$ & $72.67^{\mathrm{ijk}}$ & $1.37^{\mathrm{ijk}}$ & $22.05^{a}$ & $1.40^{\mathrm{hij}}$ & $4.04^{d}$ \\
\hline & & 140 & $2.26^{\mathrm{cd}}$ & $96.75^{d}$ & $0.17^{j}$ & $72.09^{k}$ & $1.29^{\mathrm{kl}}$ & $22.37^{a}$ & $2.66^{\mathrm{hij}}$ & $4.94^{\mathrm{b}}$ \\
\hline & $\mathrm{CO}_{2}$ & 80 & $1.51^{\mathrm{gh}}$ & $57.78^{\mathrm{j}}$ & $0.45^{\mathrm{cd}}$ & $72.50^{\mathrm{jk}}$ & $1.53^{\mathrm{hij}}$ & $22.61^{a}$ & $1.27^{\mathrm{ij}}$ & $3.31^{\mathrm{ef}}$ \\
\hline & & 110 & $1.32^{\mathrm{ij}}$ & $119.75^{\mathrm{b}}$ & $0.33^{\mathrm{fgh}}$ & $80.66^{\mathrm{de}}$ & $0.12^{\mathrm{p}}$ & $19.19^{\mathrm{b}}$ & $2.57^{\mathrm{hij}}$ & $4.92^{\mathrm{bc}}$ \\
\hline & & 140 & $1.23^{j}$ & $146.63^{a}$ & $0.27^{\text {ghi }}$ & $77.95^{f}$ & $0.35^{\circ}$ & $19.34^{\mathrm{b}}$ & $2.97^{\mathrm{hij}}$ & $6.04^{a}$ \\
\hline
\end{tabular}

Different letters (a-p) in the same column are significantly different at $P<0.05$.

ER, expansion ratio; WSI, water solubility index; WAI, water absorption index.

${ }^{1)} L^{*}$, lightness; $a^{*}$, redness; $b^{*}$, yellowness.

ER in describing the degree of puffing in extrudates. The piece density in all extrudates ranged from 0.17 to 0.60 $\mathrm{g} / \mathrm{cm}^{3}$. The increasing barrel temperatures significantly decreased piece density of extruded oats with $\mathrm{CO}_{2}$ injection and extruded millet without $\mathrm{CO}_{2}$ injection $(P<0.05)$. When the barrel temperature was increased from 80 to $110^{\circ} \mathrm{C}$, the reduction of piece density was shown in extruded sorghum and extruded barley with or without $\mathrm{CO}_{2}$ injection. The raising of barrel temperature increases the degree of superheating of water in the extruder and encourages bubble formation and decrease in melt viscosity resulting in a reduction in the piece density (32). Huth et al. (29) also have reported a similar result that increased barrel temperature leads to a significant decrease in the piece density and an increase in ER of extruded barley. The $\mathrm{CO}_{2}$ injection showed a significant increase in piece density of extruded sorghum and extruded millet at $140^{\circ} \mathrm{C}$. However, a significant decrease in piece density with $\mathrm{CO}_{2}$ injection was shown in extruded sorghum, extruded barley, and extruded millet at $80^{\circ} \mathrm{C}$ and extruded oats at $140^{\circ} \mathrm{C}$.

Color: Table 1 shows a significant decrease in lightness of extruded sorghum with or without $\mathrm{CO}_{2}$ injection at $140^{\circ} \mathrm{C}$ when the barrel temperature increased. Under the $\mathrm{CO}_{2}$ injection, the lightness of extruded barley at $140^{\circ} \mathrm{C}$ and extruded millet at $110^{\circ} \mathrm{C}$ had significant increases.

In extruded sorghum with or without $\mathrm{CO}_{2}$ injection, a significant increase in redness was observed as the barrel temperature increased. When the barrel temperature increased from 80 to $110^{\circ} \mathrm{C}$, the redness of extruded barley without $\mathrm{CO}_{2}$ injection showed a significant increase and extruded oats with $\mathrm{CO}_{2}$ injection showed a significant decrease in redness. Moreover, a significant decrease in redness was observed in extruded oats without $\mathrm{CO}_{2}$ injection and extruded millet with $\mathrm{CO}_{2}$ injection.

The yellowness of extruded millet with $\mathrm{CO}_{2}$ injection (from 80 to $110^{\circ} \mathrm{C}$ ) and extruded barley with $\mathrm{CO}_{2}$ injection at $140^{\circ} \mathrm{C}$ was significantly decreased as the barrel temperature was increased. The slight increases in yellowness of extruded barley without $\mathrm{CO}_{2}$ injection and extruded millet without $\mathrm{CO}_{2}$ injection were observed, but not significant. Increase in redness and yellowness of the extrudates may have resulted from caramelization and Maillard reactions that take place during the extrusion 
process. The changes in yellowness during extrusion cooking of yellow maize were induced by the effects of two different reactions: the non-enzymatic browning and pigment destruction. Some of the carotenoids might have been damaged by the thermal treatment and some browning might have been responsible for the color loss (33). In this study, the $\mathrm{CO}_{2}$ injection did not favor the Maillard reaction in the redness of extruded sorghum, extruded barley at $140^{\circ} \mathrm{C}$, extruded oats and extruded millet, as well as the yellowness of all extrudates at higher temperatures $\left(110^{\circ} \mathrm{C}\right.$ and $\left.140^{\circ} \mathrm{C}\right)$ and extruded barley at $140^{\circ} \mathrm{C}$.

WAI and WSI: The WAI is a physico-chemical parameter that has been reported to indicate the hydrolytic breakdown of starch during extrusion (34), and the swelling behavior of the starch components (9).

There were significant increases in WAI of all extrudates after extrusion $(P<0.05)$, compared to their raw samples (Table 1). Increasing the barrel temperature had significant increases in WAI of extruded millet with or without $\mathrm{CO}_{2}$ injection and extruded sorghum without $\mathrm{CO}_{2}$ injection at $140^{\circ} \mathrm{C}$. The highest value of WAI $(6.04$ $\mathrm{g} / \mathrm{g}$ ) was in extruded millet with $\mathrm{CO}_{2}$ injection at $140^{\circ} \mathrm{C}$. Singh et al. (35) has reported that protein denaturation, starch gelatinization and swelling of the crude fiber, which occurred during extrusion, could all be responsible for the increased WAI of extrudates. In contrast, when the temperature increased from 80 to $110^{\circ} \mathrm{C}$, extruded barley with or without $\mathrm{CO}_{2}$ injection showed a significant decrease in WAI. Ng et al. (36) reported that increasing the die temperature during the extrusion of onion waste decreased WAI and increased WSI. In extruded millet, WAI with $\mathrm{CO}_{2}$ injection was significantly increased and was higher than that of extruded millet without $\mathrm{CO}_{2}$ injection.

WSI has been reported to represent the extent of soluble polysaccharides released from the grain in excess water (9). After extrusion, the significant increase of WSI was shown in extruded sorghum (Table 1). There was a significant decrease in WSI of extruded oats and extruded millet compared to their raw samples. The WSI ranged from 1.19 to $10.97 \%$. The significant increase of WSI (1.19 to $2.66 \%$ ) was shown especially in extruded millet (without $\mathrm{CO}_{2}$ injection) with increasing temperature from 80 to $140^{\circ} \mathrm{C}$. On the other hand, extruded sorghum with $\mathrm{CO}_{2}$ injection showed a significant decrease (from 10.97 to $5.82 \%)$ due to higher barrel temperature $(P<$ $0.05)$. Singkhornart et al. (16) reported that a decrease in the macro-molecular degradation during extrusion with the increase in barrel temperatures could be responsible for the decreased WSI of extrudates.

\section{Chemical properties}

PD: As shown in Table 2, the highest value (83.7\%) of PD was shown in millet among the tested raw cereals. After
Table 2. Effects of $\mathrm{CO}_{2}$ injection and barrel temperatures on the chemical properties of extruded cereals

\begin{tabular}{|c|c|c|c|c|c|}
\hline Sample & $\begin{array}{c}\mathrm{CO}_{2} \\
\text { injection }\end{array}$ & $\begin{array}{c}\text { Temperature } \\
\left({ }^{\circ} \mathrm{C}\right)\end{array}$ & $\begin{array}{l}\text { PD } \\
(\%)\end{array}$ & $\begin{array}{l}\beta-\text {-Glucan } \\
(\% \mathrm{w} / \mathrm{w})\end{array}$ & $\begin{array}{c}\text { RS } \\
(\mathrm{g} / 100 \mathrm{~g})\end{array}$ \\
\hline \multirow[t]{7}{*}{ Sorghum } & Raw & - & $81.58^{b}$ & $0.10^{h}$ & $0.69^{b}$ \\
\hline & Non- $\mathrm{CO}_{2}$ & 80 & $40.77^{e}$ & $0.21^{\mathrm{h}}$ & $0.25^{\text {cdefgh }}$ \\
\hline & & 110 & $30.79^{f}$ & $0.11^{\mathrm{h}}$ & $0.24^{\text {cdefgh }}$ \\
\hline & & 140 & $56.55^{d}$ & $0.27^{h}$ & $0.35^{\text {bcdefgh }}$ \\
\hline & $\mathrm{CO}_{2}$ & 80 & $42.33^{\mathrm{e}}$ & $0.26^{h}$ & $0.48^{\text {bcde }}$ \\
\hline & & 110 & $34.37^{\text {ef }}$ & $0.07^{h}$ & $0.43^{\text {bcdefg }}$ \\
\hline & & 140 & $65.50^{c}$ & $0.06^{\mathrm{h}}$ & $0.52^{b c}$ \\
\hline \multirow[t]{7}{*}{ Barley } & Raw & - & $64.85^{c}$ & $2.92^{f}$ & $1.06^{a}$ \\
\hline & Non- $\mathrm{CO}_{2}$ & 80 & $84.17^{b}$ & $4.35^{\text {cde }}$ & $0.16^{\text {cdefgh }}$ \\
\hline & & 110 & $86.90^{b}$ & $4.61^{b c}$ & $0.28^{\text {cdefgh }}$ \\
\hline & & 140 & $86.85^{\mathrm{b}}$ & $4.54^{\mathrm{bcd}}$ & $0.22^{\text {cdefgh }}$ \\
\hline & $\mathrm{CO}_{2}$ & 80 & $86.19^{b}$ & $4.92^{\mathrm{ab}}$ & $0.19^{\text {cdefgh }}$ \\
\hline & & 110 & $85.27^{b}$ & $4.99^{\mathrm{ab}}$ & $0.30^{\text {bcdefgh }}$ \\
\hline & & 140 & $98.87^{\mathrm{a}}$ & $5.24^{a}$ & $0.34^{\text {bcdefgh }}$ \\
\hline \multirow[t]{7}{*}{ Oats } & Raw & - & $65.76^{\mathrm{C}}$ & $2.07^{9}$ & $0.45^{\text {bcdef }}$ \\
\hline & Non- $\mathrm{CO}_{2}$ & 80 & $83.15^{b}$ & $3.95^{\mathrm{e}}$ & $0.06^{\text {fgh }}$ \\
\hline & & 110 & $83.57^{b}$ & $4.08^{\text {cde }}$ & $0.09^{\text {efgh }}$ \\
\hline & & 140 & $83.75^{b}$ & $3.98^{\mathrm{de}}$ & $0.10^{\text {defgh }}$ \\
\hline & $\mathrm{CO}_{2}$ & 80 & $83.86^{\mathrm{b}}$ & $4.14^{\text {cde }}$ & $0.11^{\text {defgh }}$ \\
\hline & & 110 & $83.59^{b}$ & $4.10^{\text {cde }}$ & $0.10^{\text {defgh }}$ \\
\hline & & 140 & $89.99^{b}$ & $4.19^{\text {cde }}$ & $0.35^{\text {bcdefgh }}$ \\
\hline \multirow[t]{7}{*}{ Millet } & Raw & - & $83.70^{b}$ & $0.05^{\mathrm{h}}$ & $0.50^{b c d}$ \\
\hline & Non- $\mathrm{CO}_{2}$ & 80 & $52.57^{d}$ & $0.08^{h}$ & $0.22^{\text {cdefgh }}$ \\
\hline & & 110 & $66.30^{c}$ & $0.09^{h}$ & $0.11^{\text {cdefgh }}$ \\
\hline & & 140 & $84.46^{\mathrm{b}}$ & $0.06^{\mathrm{h}}$ & $0.02^{h}$ \\
\hline & $\mathrm{CO}_{2}$ & 80 & $55.49^{d}$ & $0.08^{h}$ & $0.38^{\text {bcdefgh }}$ \\
\hline & & 110 & $80.46^{b}$ & $0.12^{h}$ & $0.12^{\text {cdefgh }}$ \\
\hline & & 140 & $90.10^{b}$ & $0.16^{h}$ & $0.03^{g h}$ \\
\hline
\end{tabular}

Different letters (a-h) in the same column are significantly different at $P<0.05$.

Each sample was measured in triplicates.

extrusion, extruded barley and extruded oats showed a significant increase in PD compared to their raw materials. Our result was in accordance with the report of Abd El-Hady and Habiba (37). After extrusion, extruded sorghum showed a significant reduction in PD followed by the extruded millet. This may be due to their highly hydrophobic nature and inaccessibility of the protein bodies to enzymatic attack (25).

Increasing barrel temperature significantly improved the PD of extruded millet with or without $\mathrm{CO}_{2}$ injection and extruded barley with $\mathrm{CO}_{2}$ injection $\left(140^{\circ} \mathrm{C}\right)$. A similar influence of extrusion temperature on in vitro $\mathrm{PD}$ of extruded 2 low tannin sorghum varieties have been reported by Fapojuwo et al. (12). In addition, extrusion cooking, especially under the highest barrel temperature $\left(140^{\circ} \mathrm{C}\right)$, resulted in higher PD in all extrudates with or without $\mathrm{CO}_{2}$ injection, especially in extruded barley (98.87\%). The increase in PD in wheat flour has been reported by Singh et al. (38). This indicates that a higher temperature enhances the degree of inactivation of protease inhibitors, causing an increase in PD. In extruded 
sorghum with or without $\mathrm{CO}_{2}$ injection, $\mathrm{PD}$ was significantly decreased at $110^{\circ} \mathrm{C}$ and then increased at $140^{\circ} \mathrm{C}$. This could be due to the formation of either a disulfidebound protein coat produced by proteins surrounding the protein body or an anterior "toughening" of the periphery of the protein body because of disulfide bond formation (25).

Extrudates with $\mathrm{CO}_{2}$ injection showed higher values in $\mathrm{PD}$ than the ones that were not injected with $\mathrm{CO}_{2}$. The dissolution of $\mathrm{CO}_{2}$ in the aqueous phase of the feed during the $\mathrm{CO}_{2}$ injection process is expected to decrease $\mathrm{pH}$. Onyango et al. (39) also reported that a low $\mathrm{pH}$ promotes structural changes and denaturation of storage proteins and increase their accessibility to proteolytic enzymes.

$\beta$-Glucan: The $\beta$-glucan content in all extrudates ranged from 0.06 to $5.24 \%(\mathrm{w} / \mathrm{w})$. Extrusion can significantly influence the $\beta$-glucan content of extruded barley and extruded oats $(P<0.05)$ compared to their raw materials. Similarly, Singkhornart et al. (40) reported that the increase in $\beta$-glucan content was observed in extruded whole germinated wheat. It could be that the insoluble $\beta$-glucan becomes water-extractable by high shear force and temperature during the extrusion process. In addition, our results are in agreement with the report on extruding waxy barley, whole barley grains, or barley bran which shows a significant increase in the content of soluble dietary fiber (41). This effect is mainly attributed to an increase in solubility of $\beta$-glucan.

By contrast, there was no significant increase in the $\beta$ glucan content of extruded sorghum and extruded millet compared to their raw materials. Moreover, changing the barrel temperature did not affect the $\beta$-glucan content of all extrudates. This was in agreement with Yao et al. (15), who reported that the impact of extrusion temperature and moisture content did not affect the $\beta$-glucan concentration of oat. The maximum value (5.24\%) of $\beta$-glucan content was shown in extruded barley at $140^{\circ} \mathrm{C}$ with $\mathrm{CO}_{2}$ injection. The effect of $\mathrm{CO}_{2}$ injection on $\beta$-glucan concentration was shown in extruded barley $\left(80^{\circ} \mathrm{C}\right.$ and $\left.140^{\circ} \mathrm{C}\right)$ with a significant increase.

$R S: \mathrm{RS}$ is the starch or the product of starch degradation that escapes digestion in the small intestine of healthy individuals and may be completely or partially fermented in the colon (42).

As shown in Table 2, the RS content of extruded sorghum and extruded barley was significantly decreased after extrusion $(P<0.05)$ compared to their respective raw materials. The RS value of all extrudates ranged from 0.02 to $0.52 \%(\mathrm{~g} / 100 \mathrm{~g})$. Under higher temperatures, RS in all extrudates except extruded millet without $\mathrm{CO}_{2}$ injection increased with no significance.

Our results are in agreement with the report of Faraj et al. (11) that starch fragmentation readily occurs at higher temperatures at the specified moisture content leading to the formation of amylose chains (with reduced degree of polymerization) that could be incorporated into the crystalline structure of $\mathrm{RS}_{3}$. In contrast, the decrease of RS was shown in extruded millet without $\mathrm{CO}_{2}$ injection due to the increase in barrel temperature. It could be due to the low amylose content, which was also reported by Vasanthan et al. (43). The effect of $\mathrm{CO}_{2}$ injection was observed in all extrudates, but was deemed not significant.

\section{Antioxidant properties}

TPC: While extrusion cooking showed a significant decrease in TPC of extruded sorghum $(P<0.05)$, extruded barley and extruded oats, a slight increase was shown in extruded millet compared to their raw materials (Table 3). The TPC losses in this study were consistent with previous reports, showing a decrease in TPC of oat cereals and oat extrudates by $24 \sim 46$ and $50 \%$, respectively (17,

Table 3. Effects of $\mathrm{CO}_{2}$ injection and barrel temperatures on the antioxidant properties of extruded cereals

\begin{tabular}{|c|c|c|c|c|c|}
\hline Sample & $\begin{array}{c}\mathrm{CO}_{2} \\
\text { injection }\end{array}$ & $\begin{array}{c}\text { Temperature } \\
\left({ }^{\circ} \mathrm{C}\right)\end{array}$ & $\begin{array}{c}\text { TPC (mg } \\
\text { GAE/g) }\end{array}$ & $\begin{array}{c}\text { TFC (mg } \\
Q E / g)\end{array}$ & DPPH \\
\hline \multirow[t]{7}{*}{ Sorghum } & Raw & - & $32.69^{a}$ & $2.89^{\text {cdefg }}$ & $38.91^{a}$ \\
\hline & $\mathrm{Non}-\mathrm{CO}_{2}$ & 80 & $20.8^{c}$ & $2.84^{\text {defg }}$ & $9.65^{\text {defg }}$ \\
\hline & & 110 & $19.54^{\mathrm{c}}$ & $3.11^{\text {abcdef }}$ & $9.15^{\mathrm{fg}}$ \\
\hline & & 140 & $14.85^{\mathrm{ef}}$ & $3.48^{\mathrm{abc}}$ & $11.22^{\text {bcde }}$ \\
\hline & $\mathrm{CO}_{2}$ & 80 & $24.11^{b}$ & $2.58^{\text {efgh }}$ & $12.89^{b}$ \\
\hline & & 110 & $20.53^{c}$ & $2.61^{\text {defgh }}$ & $11.94^{\mathrm{bc}}$ \\
\hline & & 140 & $17.35^{d}$ & $2.96^{\text {bcdefg }}$ & $11.40^{\mathrm{bcd}}$ \\
\hline \multirow[t]{7}{*}{ Barley } & Raw & - & $15.38^{\mathrm{e}}$ & $1.84^{\mathrm{jkl}}$ & $4.69^{\mathrm{j}}$ \\
\hline & Non- $\mathrm{CO}_{2}$ & 80 & $7.46^{\mathrm{kl}}$ & $1.59^{\prime}$ & $4.56^{\mathrm{j}}$ \\
\hline & & 110 & $8.98^{\mathrm{jk}}$ & $2.45^{\text {ghij }}$ & $4.56^{\mathrm{j}}$ \\
\hline & & 140 & $11.66^{\mathrm{hi}}$ & $2.46^{\text {ghij }}$ & $5.32^{\mathrm{ij}}$ \\
\hline & $\mathrm{CO}_{2}$ & 80 & $8.67^{\mathrm{jkl}}$ & $1.76^{\mathrm{kl}}$ & $5.72^{\mathrm{ij}}$ \\
\hline & & 110 & $10.11^{\mathrm{ij}}$ & $2.32^{\text {ghijk }}$ & $4.42^{j}$ \\
\hline & & 140 & $14.65^{\mathrm{efg}}$ & $2.52^{\text {efghi }}$ & $6.19^{i j}$ \\
\hline \multirow[t]{7}{*}{ Oats } & Raw & - & $20.45^{c}$ & $2.86^{\text {cdefg }}$ & $10.04^{\text {cdefg }}$ \\
\hline & Non- $\mathrm{CO}_{2}$ & 80 & $14.22^{\text {efg }}$ & $3.65^{\mathrm{a}}$ & $8.42^{\mathrm{gh}}$ \\
\hline & & 110 & $13.28^{\text {fgh }}$ & $3.24^{\mathrm{abcd}}$ & $9.45^{\text {efg }}$ \\
\hline & & 140 & $12.74^{\mathrm{gh}}$ & $2.50^{\text {fghi }}$ & $10.41^{\text {cdef }}$ \\
\hline & $\mathrm{CO}_{2}$ & 80 & $14.28^{\mathrm{efg}}$ & $3.56^{\mathrm{ab}}$ & $8.20^{\text {gh }}$ \\
\hline & & 110 & $13.29^{\mathrm{fgh}}$ & $3.15^{\text {abcde }}$ & $10.12^{\text {cdefg }}$ \\
\hline & & 140 & $13.29^{\mathrm{fgh}}$ & $2.37^{\text {ghijk }}$ & $10.04^{\text {cdefg }}$ \\
\hline \multirow[t]{7}{*}{ Millet } & Raw & - & $6.79^{1}$ & $1.58^{\prime}$ & $8.20^{g h}$ \\
\hline & Non- $\mathrm{CO}_{2}$ & 80 & $7.34^{\mathrm{kl}}$ & $1.69^{\prime}$ & $5.24^{\mathrm{ij}}$ \\
\hline & & 110 & $7.49^{k l}$ & $1.98^{\mathrm{hijkl}}$ & $5.54^{\mathrm{ij}}$ \\
\hline & & 140 & $8.61^{\mathrm{jkl}}$ & $2.39^{\mathrm{ghijk}}$ & $6.87^{\mathrm{hi}}$ \\
\hline & $\mathrm{CO}_{2}$ & 80 & $8.12^{\mathrm{jkl}}$ & $1.91^{\mathrm{ijkl}}$ & $5.10^{\mathrm{ij}}$ \\
\hline & & 110 & $9.53^{j}$ & $2.10^{\mathrm{hijkl}}$ & $5.69^{\mathrm{ij}}$ \\
\hline & & 140 & $9.83^{i j}$ & $2.38^{\text {ghijk }}$ & $8.42^{g h}$ \\
\hline
\end{tabular}

Different letters $(a-l)$ in the same column are significantly different at $P<0.05$.

The concentration of total phenolic content (TPC) and total flavonoid content (TFC) were determined as milligrams of gallic acid equivalent (GAE) and quercetin equivalent (QE) per gram of dry sample, respectively.

Each sample was measured in triplicates. 
18). The observed increase in TPC was consistent with Nayak et al. (44), who reported that TPC of extruded purple potato flour mix increased compared with the nonextruded product.

The TPC content of all extrudates ranged from 7.34 to $24.11 \mathrm{mg}$ GAE/g (Table 3). The highest TPC value (24.11 mg GAE/g) was shown in extruded sorghum. Increasing barrel temperatures $\left(140^{\circ} \mathrm{C}\right)$ caused the significant decrease in TPC of extruded sorghum with $\mathrm{CO}_{2}$ injection and extruded sorghum without $\mathrm{CO}_{2}$ injection. It has been stated that high temperatures during extrusion can alter molecular structure of phenolic compounds and either reduce their chemical reactivity or decrease their extractability due to a certain degree of polymerization causing the loss of antioxidant properties (17). In contrast, there was a significant increase in TPC in extruded barley with or without $\mathrm{CO}_{2}$ injection at $140^{\circ} \mathrm{C}$ due to a higher barrel temperature. An increase was shown in extruded millet with or without $\mathrm{CO}_{2}$ injection but was not significant. This may be due to the release of total phenolics from the cell wall matrix (45) caused by harsh thermal processing. Generally, TPC of all extrudates was slightly affected by injection of $\mathrm{CO}_{2}$ during extrusion. The $\mathrm{CO}_{2}$ injection significantly affected TPC of extruded sorghum $\left(80^{\circ} \mathrm{C}\right.$ and $140^{\circ} \mathrm{C}$ ), extruded millet at $110^{\circ} \mathrm{C}$, and extruded barley at $140^{\circ} \mathrm{C}$ within the same conditions. These results may be attributed to the cooling effect of the $\mathrm{CO}_{2}$ (46) and its relatively low chemical reactivity.

TFC: Flavonoids have generated interest because of their broad effects in promoting health, most of which are related to their antioxidant properties and their synergistic effects with other antioxidants (47).

Among the cereals, extruded sorghum and extruded barley had a decrease in TFC in comparison with their raw samples. Shimelis and Pakshit (48) reported that extrusion cooking has been used to bring numerous chemical changes such as gelatinization of starch, denaturation of protein, losses of lipid, and inactivation of enzymes resulting in a reduction of flavonoid compounds. On the other hand, a significant $(P<0.05)$ increase in TFC was shown in extruded oats $(P<0.05)$. Decreasing TFC in extruded oats with or without $\mathrm{CO}_{2}$ injection $\left(\right.$ at $140^{\circ} \mathrm{C}$ ) was observed due to increasing barrel temperatures. This may be attributed to the thermal destruction of flavonoids, as flavonoids are reported to be heat sensitive (49). In contrast, a slight increase was observed in extruded sorghum, extruded barley and extruded millet (with or without $\mathrm{CO}_{2}$ injection) when the barrel temperature during extrusion increased. The increase in TFC due to $\mathrm{CO}_{2}$ injection was only observed in extruded barley $\left(80^{\circ} \mathrm{C}\right.$ and $\left.140^{\circ} \mathrm{C}\right)$ and extruded millet $\left(80^{\circ} \mathrm{C}\right.$ and $\left.110^{\circ} \mathrm{C}\right)$, respectively (Table 3 ).

DPPH radical scavenging activity: The DPPH free-radical as- say was used to estimate the antioxidant activity by its ability to attract hydrogen atoms from polyphenols. The degree of discoloration indicates the scavenging potential of the sample total antioxidant capacity (50).

The significant decrease in DPPH radical scavenging activity was observed in extruded sorghum and extruded millet compared to their raw samples (Table 3). The DPPH value $(38.91 \%)$ of sorghum was highest in raw cereals and significantly decreased to $9.65 \%$ after extrusion. This result was in agreement with that reported by Altan et al. (14). When the barrel temperature was increased, an increase was observed in DPPH radical scavenging activity of all extrudates except extruded sorghum with $\mathrm{CO}_{2}$ injection. When the barrel temperature increased from $80^{\circ} \mathrm{C}$ to $110^{\circ} \mathrm{C}$, a slight decrease was found in extruded sorghum without $\mathrm{CO}_{2}$ injection and in extruded barley with $\mathrm{CO}_{2}$ injection, and an increase was observed for both at $140^{\circ} \mathrm{C}$. The significant increase was shown in extruded millet with $\mathrm{CO}_{2}$ injection, when the barrel temperature increased from $110^{\circ} \mathrm{C}$ to $140^{\circ} \mathrm{C}$. Similarly, Sharma et al. (6) also explained that increased DPPH radical scavenging activity of barley extrudates was due to the formation of brown color pigments from Maillard browning reaction during extrusion. A change in the extrusion temperature and moisture could have lead to the formation of different amounts of Maillard browning products (51). The significant effect of $\mathrm{CO}_{2}$ injection on DPPH was observed in the sorghum extrudate at $80^{\circ} \mathrm{C}$ and $110^{\circ} \mathrm{C}$, respectively.

Extrusion conditions in this study induced significant changes in some physical properties of all extrudates. Under a higher barrel temperature, extruded barley with or without $\mathrm{CO}_{2}$ injection at $140^{\circ} \mathrm{C}$ showed a significant increase in TPC. The significant increase in DPPH of millet without $\mathrm{CO}_{2}$ injection at $140^{\circ} \mathrm{C}$ and $\mathrm{PD}$ of extruded sorghum with or without $\mathrm{CO}_{2}$ injection, extruded barley with $\mathrm{CO}_{2}$ injection at $140^{\circ} \mathrm{C}$, and extruded millet with or without $\mathrm{CO}_{2}$ injection was due to higher barrel temperatures. The $\mathrm{CO}_{2}$ injection had a significant effect in some physical properties (ER, specific length, piece density, color, and WAI). Moreover, the $\mathrm{CO}_{2}$ injection caused a positive effect on some antioxidant properties (TPC and $\mathrm{DPPH})$ and chemical properties ( $\beta$-glucan and PD). Results from this study showed that millet and barley have higher potential for cereal-based extruded foods than other cereals.

\section{ACKNOWLEDGEMENTS}

This research was supported by the Basic Science Research Program through the National Research Foundation of Korea (NRF) funded by the Ministry of Education, Science and Technology (2015R1A1A4A03004018). 


\section{AUTHOR DISCLOSURE STATEMENT}

The authors declare no conflict of interest.

\section{REFERENCES}

1. Awika JM, McDonough CM, Rooney LW. 2005. Decorticating sorghum to concentrate healthy phytochemicals. J Agric Food Chem 53: 6230-6234.

2. Deshpande HW, Poshadri A. 2011. Physical and sensory characteristics of extruded snacks prepared from Foxtail millet based composite flours. Int Food Res J 18: 751-756.

3. Jadhav SJ, Lutz SE, Ghorpade VM, Salunkhe DK. 1998. Barley: chemistry and value-added processing. Crit Rev Food Sci Nutr 38: 123-171.

4. Peterson DM, Emmons CL, Hibbs AH. 2001. Phenolic antioxidants and antioxidant activity in pearling fractions of oat groats. J Cereal Sci 33: 97-103.

5. Ryu GH, Walker CE. 1995. The effects of extrusion conditions on the physical properties of wheat flour extrudates. Starch 47: 33-36.

6. Sharma P, Gujral HS, Singh B. 2012. Antioxidant activity of barley as affected by extrusion cooking. Food Chem 131: 14061413.

7. Mulvaney SJ, Rizvi SSH. 1993. Extrusion processing with supercritical fluids. Food Technol 47: 74-82.

8. Plews AG, Atkinson A, Trampe T, Mcgrane S. 2009. Control of porosity and expansion in starch extrusion by monitoring pressure at die outlet. J Cell Plast 45: 67-82.

9. White GA, Doucet FJ, Hill SE, Wiseman J. 2008. Physicochemical properties and nutritional quality of raw cereals for newly weaned piglets. Animal 2: 867-878.

10. Rabe E, Sievert D. 1992. Effects of baking, pasta production, and extrusion cooking on formation of resistant starch. Eur J Clin Nutr 46: S105-S107.

11. Faraj A, Vasanthan T, Hoover R. 2004. The effect of extrusion cooking on resistant starch formation in waxy and regular barley flours. Food Res Int 37: 517-525.

12. Fapojuwo OO, Maga JA, Jansen GR. 1987. Effect of extrusion cooking on in vitro protein digestibility of sorghum. J Food Sci 52: 218-219.

13. Ejeta G, Hassen MM, Mertz ET. 1987. In vitro digestibility and amino acid composition of pearl millet (Pennisetum typhoides) and other cereals. Proc Natl Acad Sci USA 84: 6016-6019.

14. Altan A, McCarthy KL, Maskan M. 2009. Effect of extrusion process on antioxidant activity, total phenolics and $\beta$-glucan content of extrudates developed from barley-fruit and vegetable by-products. Int J Food Sci Technol 44: 1263-1271.

15. Yao N, Jannink JL, Alavi S, White PJ. 2006. Physical and sensory characteristics of extruded products made from two oat lines with different $\beta$-glucan concentrations. Cereal Chem 83: 692-699.

16. Singkhornart S, Gu BJ, Ryu GH. 2013. Physicochemical properties of extruded germinated wheat and barley as modified by $\mathrm{CO}_{2}$ injection and difference extrusion conditions. Int $\mathrm{J}$ Food Sci Technol 48: 290-299.

17. Zadernowskl R, Nowak-Polakowska H, Rashed AA. 1999. The influence of heat treatment on the activity of lipo- and hydrophilic components of oat grain. J Food Process Preserv 23: 177-191.

18. Viscidi KA, Dougherty MP, Briggs J, Camire ME. 2004. Complex phenolic compounds reduce lipid oxidation in extruded oat cereals. LWT-Food Sci Technol 37: 789-796.

19. Carvalho CWP, Mitchell JR. 2000. Effect of sugar on the ex- trusion of maize grits and wheat flour. Int J Food Sci Technol 35: $569-576$.

20. AOAC. 1990. Official method of analysis. 15th ed. Association of Official Analytical Chemists, Washington, DC, USA. p 69.

21. Lee EY, Ryu GH, Lim ST. 1999. Effects of processing parameters on physical properties of corn starch extrudates expanded using supercritical $\mathrm{CO}_{2}$ injection. Cereal Chem 76: 63-69.

22. Anderson RA, Conway HF, Pfeifer VF, Griffin ELJr. 1969. Gelatinization of corn grits by roll and extrusion-cooking. Cereal Sci Today 14: 4-12.

23. Mertz ET, Hassen MM, Cairns-Whittern C, Kirleis AW, Tu L, Axtell JD. 1984. Pepsin digestibility of proteins in sorghum and other major cereals. Proc Natl Acad Sci USA 81: 1-2.

24. Starcher B. 2001. A ninhydrin-based assay to quantitate the total protein content of tissue samples. Anal Biochem 292: 125129.

25. Hamaker BR, Kirleis AW, Butler LG, Axtell JD, Mertz ET. 1987. Improving the in vitro protein digestibility of sorghum with reducing agents. Proc Natl Acad Sci USA 84: 626-628.

26. Slinkard K, Singleton VL. 1977. Total phenol analysis: automation and comparison with manual methods. Am J Enol Vitic 28: 49-55.

27. Ebrahimzadeh MA, Pourmorad F, Bekhradnia AR. 2008. Iron chelating activity, phenol and flavonoid content of some medicinal plants from Iran. Afr J Biotechnol 7: 3188-3192.

28. Brand-Williams W, Cuvelier ME, Berset C. 1995. Use of a free radical method to evaluate antioxidant activity. LWT-Food Sci Technol 28: 25-30.

29. Huth M, Dongowski G, Gebhardt E, Flamme W. 2000. Functional properties of dietary fibre enriched extrudates from barley. J Cereal Sci 32: 115-128.

30. Kokini JL, Chang CN, Lai LS. 1992. The role of rheological properties on extrudate expansion. In Food Extrusion Science and Technology. Kokini JL, Ho CT, Karwe MV, eds. Marcel Dekker Inc., New York, NY, USA. p 631-652.

31. Altan A, McCarthy KL, Maskan M. 2008. Twin-screw extrusion of barley-grape pomace blends: extrudate characteristics and determination of optimum processing conditions. J Food Eng 89: 24-32.

32. Fletcher SI, Richmond P, Smith AC. 1985. An experimental study of twin-screw extrusion-cooking of maize grits. J Food Eng 4: 291-312.

33. Ilo S, Berghofer E. 1999. Kinetics of colour changes during extrusion cooking of maize grits. J Food Eng 39: 73-80.

34. Owusu-Ansah J, van de Voort FR, Stanley DW. 1983. Physicochemical changes in cornstarch as a function of extrusion variables. Cereal Chem 60: 319-324.

35. Singh B, Sekhon KS, Singh N. 2007. Effects of moisture, temperature and level of pea grits on extrusion behaviour and product characteristics of rice. Food Chem 100: 198-202.

36. Ng A, Lecain S, Parker ML, Smith AC, Waldron KW. 1999. Modification of cell-wall polymers of onion waste: III. Effect of extrusion-cooking on cell-wall material of outer fleshy tissues. Carbohydr Polym 39: 341-349.

37. Abd El-Hady EA, Habiba RA. 2003. Effect of soaking and extrusion conditions on antinutrients and protein digestibility of legume seeds. LWT-Food Sci Technol 36: 285-293.

38. Singh S, Gamlath S, Wakeling L. 2007. Nutritional aspects of food extrusion: a review. Int J Food Sci Technol 42: 916-929.

39. Onyango C, Noetzold H, Ziems A, Hofmann T, Bley T, Henle T. 2005. Digestibility and antinutrient properties of acidified and extruded maize-finger millet blend in the production of uji. LWT-Food Sci Technol 38: 687-707.

40. Singkhornart S, Edou-ondo S, Ryu GH. 2014. Influence of germination and extrusion with $\mathrm{CO}_{2}$ injection on physicochemical properties of wheat extrudates. Food Chem 143: 122-131.

41. Marlett JA. 1991. Dietary fiber content and effect of process- 
ing on two barley varieties. Cereal Food World 36: 576-578.

42. Englyst HN, Kingman SM, Cummings JH. 1992. Classification and measurement of nutritionally important starch fractions. Eur J Clin Nutr 46: S30-S50.

43. Vasanthan T, Gaosong J, Yeung J, Li J. 2002. Dietary fiber profile of barley flour as affected by extrusion cooking. Food Chem 77: 35-40.

44. Nayak B, Liu RH, Berrios Jde J, Tang J, Derito C. 2011. Bioactivity of antioxidants in extruded products prepared from purple potato and dry pea flours. J Agric Food Chem 59: 82338243.

45. Brennan C, Brennan M, Derbyshire E, Tiwari BK. 2011. Effects of extrusion on the polyphenols, vitamins and antioxidant activity of foods. Trends Food Sci Technol 22: 570-575.

46. Wang YY, Ryu GH. 2013. Physicochemical and antioxidant properties of extruded corn grits with corn fiber by $\mathrm{CO}_{2}$ injection extrusion process. J Cereal Sci 58: 110-116.

47. Sharma P, Gujral HS. 2011. Effect of sand roasting and mi- crowave cooking on antioxidant activity of barley. Food Res Int 44: $235-240$

48. Shimelis EA, Rakshit SK. 2007. Effect of processing on antinutrients and in vitro protein digestibility of kidney bean (Phaseolus vulgaris L.) varieties grown in East Africa. Food Chem 103: 161-172.

49. Xu B, Chang SKC. 2008. Total phenolics, phenolic acids, isoflavones, and anthocyanins and antioxidant properties of yellow and black soybeans as affected by thermal processing. $J$ Agric Food Chem 56: 7165-7175.

50. Vinson JA, Proch J, Bose P. 2001. Determination of quantity and quality of polyphenol antioxidants in foods and beverages. Methods Enzymol 335: 103-114.

51. Manzocco L, Calligaris S, Mastrocola D, Nicoli M, Lerici CR. 2000. Review of non-enzymatic browning and antioxidant capacity in processed foods. Trends Food Sci Technol 11: 340346. 